\title{
A büntetőjog lehetőségei és korlátai rizikótársadalomban
}

\author{
(A büntetőjog szabályozó szerepének megváltozása \\ a posztmodernitás időszakában)
}

\begin{abstract}
Második modernitás - bünözésmenedzselés - kockázatorientált rendészet rizikótársadalom - globalizáció
\end{abstract}

A 20. század utolsó évtizedeiben gyorsulni kezdett a világ modernizációja. Ez a folyamat átmenetet jelent a második modernizációba. A rizikótársadalom új, korábban ismeretlen kihívások elé állította a világ döntéshozóit. Ennek következménye, hogy a büntetőjog a maga hagyományos eszköztárával gyakran már nem tud a társadalomra súlyosan veszélyes új típusú cselekményekre megfelelően válaszolni. Ezért paradigmaváltásra van szükség. A rizikótársadalom körülményei között a feladat: előny/hátrány, illetve költség/haszon elemzés segítségével ki kell választani azokat a cselekményeket, amelyek alakulását a büntetőjog továbbra is sikeresen képes befolyásolni. A büntetőjog által befolyásolhatatlan, ám a társadalmak működésére ma még jórészt ismeretlen mértékű súlyos veszélyek ellen büntetőjogon kívüli eszközökkel kell fellépni.

\section{Bünözésmenedzselés a 21. században ${ }^{1}$}

Közhelyszámba megy már lassan annak hangsúlyozása, hogy a 2001. évi, a Világkereskedelmi Központot ért merénylet átalakította a világ biztonságát. $A$ földkerekség államai közötti problémák fontosabbakká váltak, mint az egyes államokon belüli konfliktusok. ${ }^{2}$ Ez nemcsak a terrorizmusra érvényes, hanem ezzel egy időben elötérbe kerültek a kockázatok egyéb formái is, kezdve a környezeti gondoktól a népvándorlásokig. ${ }^{3}$ Ezeknek a bủnözésre gyakorolt hatásait sem lehet a továbbiakban másodrendű kérdésekként kezelni. Ezért a globális világ fogalmának helyét egyre

* Dr. Irk Ferenc egyetemi tanár, Rendőrtiszti Főiskola Közbiztonsági Tanszék; tanácsadó, Országos Kriminológiai Intézet. www.irkferenc.hu, dr.irk@t-online.hu.

1 Erröl forrásmunkaként I. pl. AAs, Katja Franco: Analysing a World in Motion: global flows meet criminology of the other. Theoretical Criminology Vol. 11(2): 283-303.

2 National Commission on Terrorist Attacks Upon the United States. The 9/11 Report. New York: St Martin's Press, 2004, 517. Idézi: Aas, i. m., 284.

3 Ezt 2011-ben tovább fokozták a korábban többé-kevésbé stabilnak látszó észak-afrikai és közel-keleti muzulmán országokban - az ún. fejlett országok vezetőinek többsége számára teljesen váratlanul, s egyúttal láncreakció-szerüen - kirobbant „forradalmi” események. 
inkább a globális világ mozgásaival kapcsolatos elemzések veszik át. („World in motion” - „Mozgásban a világ”. ${ }^{4}$ Számos globális hatás minden korábbinál jelentősebb következményt von maga után mind kapcsolataink, mind a helyi közösségek élete, mind morális és kulturális értékrendszereink vonatkozásában. A nemzeti határokat átlépő különféle tevékenységek, kezdve az emberkereskedelemtöl, a szexturizmuson át a számítógépes kapcsolatok legkülönfélébb megnyilvánulásaiig, a helyi viszonyokat mélyebben alakítják, mint azt sokan tudni vélik. Ez a kriminológiára sem marad hatás nélkül, aminek következtében e szakterületen mindinkább elterjedni látszik a „mozgásban a kriminológia” (,,criminology in motion”) fogalom, és a mögötte meghúzódó gondolkodásrendszer. ${ }^{5}$ Ennek föként a büntetésre és a szociális kontrollra gyakorolt hatását látszik célszerünek alaposan elemezni. Ezt célozza a mobilitás kriminológiája („criminology of mobilites”) művelésének elindítása, ami szoros összefüggést mutat az ún. második modernitás tanai köré csoportosított gondolatok kriminológiai elméletbe való átültetésével. ${ }^{6}$

Ennek a szemléletnek a gyökerei Ulrich Beck téziseiben lelhetők fel, leginkább abban, hogy az államok elveszítették ellenőrzésüket a globális kockázatok felett. ${ }^{7}$

A mobilitás egyébként megbontja a hagyományos értékrenden alapuló társadalmak belső kohézióját. Már a chicagói iskola képviselői is rámutattak arra, hogy a modern mobilitás részint dezorientáló hatású, részint lerombolja a helyi bázisokra épülő szociális kontrollt. ${ }^{8}$ Ők még elsősorban a bevándorlókra és a menedékkérőkre utaltak, akik a hagyományos társadalmi formációkat két részre bontják: „mi” és „ő”. Ezt a szemléletet erősítette a média azzal, hogy előszeretettel adott híreket a "deviáns" bevándorlókról. Lényegében ugyanez a folyamat játszódott le - némi időbeli eltolódással - Európában is, ahol szintén az „idegenek” és a „kvázi idegenek”, az etnikai kisebbségek lettek Európa „feketéi”, kerültek a deviáns csoportok centrumába - és töltötték meg a börtönöket. ${ }^{9} \mathrm{~A}$ terroristákat sokan lényegében ennek a „bűnöző kisebbségnek" a részeiként tartják nyilván, akiket - a homofóbia egy bizonyos határát túllépve már sokan úgy vélik, hogy - éppúgy száműzni kell az országból, mint valamennyi más idegent (pl. a külföldi szexrabszolgákat). A rendőrség tevékenysége számos helyen ezt a lakossági felfogásmódot és igényt igazolja vissza. ${ }^{10}$

4 INDA, Jonathan Xavier - Rosaldo, Renato (ed.): The antropology of Globalisation. A Reader, Malden, Oxford, Carlton: Blackwell, 2002.

5 L. részletesen AAs: i. m., 284. és köv.

6 Az előzményeket I. pl. HARVEY, David: The condition of postmodernity. Oxford: Basil Blackwell, 1989.; LASH, Scott - URRY, John: Economies of Signs and Space (Theory, Culture \& Society), London: Sage Publications, 1994.; CAstells, Manuel: The Rise of the Network Society, The Information Age: Economy, Society and Culture, I., Cambridge, Oxford, Blackwell, 1996.; Bauman, Zygmunt: Liquid Modernity, Cambridge: Polity, 2000. Idézi: AAs, i. m., uo.

7 Beck, Ulrich: The Terrorist Threat: World Risk Society Revisited, Theory, Culture and Society 2002, 19 (4), 47.

8 VALIER, Claire: Foreigners, Crime and Changing Mobilities, British Journal of Criminology, 2003,43 (1), 5.

9 L. erről bővebben WACQUANT, Loïc: Les Prisons de la misère, Paris: Editions Raisons d'agir, 1999, 216.; Albrecht, Hans-Jörg: Criminal Prosecution: Developments, Trends and Open Questions in the Federal Republic of Germany, European Journal of Crime, Criminal Law and Criminal Justice 8 (2000), 245-256. Idézi AAs,

10 L.: AAs, i.m., 289. és az ott idézett irodalmat. 
A határokon átívelő sokrétủ mobilitás egyik fő jellemzője - túl az exkluzió korábban ismeretlen formáin - az, hogy ezek késöbbi következményei sokkal kevésbé megbecsülhetőek, mint az országokon belüli mozgásoké. ${ }^{11}$

A jelenlegi technológiák és kulturális transzferek területenkívülisége az életröl általánosságban kérdéseket és egy sor előfeltevést vet fel. De konkrétan az is kérdés lehet, hogy ki milyen környezetet mondhat magáénak. Az ember életpályája során különféle „ablakokat” nyit ki, ami vonatkozhat akár a fizikai valóságra, akár a cybervilágra vagy a müholdak által mediatizált valóságra. A globalizáció és a változatos mobilitás elsöpri a nemzeti határokat, szétzúzza a korábban látszólag stabil kulturális és nemzeti identitás eszméit. Ferrell és társai ezért arra a következtetésre jutottak, hogy „sem a bünözés, sem a kultúra mint konstrukció a továbbiakban nem tekinthető a nemzetállamok jogi határain belül tartható jelenségnek". ${ }^{12}$ Napjaink (fizikai és képzeletbeli) mobilitásának destabilizáló tendenciái arra kényszerítenek bennünket, hogy feladjuk az utolsó kísérletét is annak, hogy a kultúra és a kulturális identitás lényegét megtartsuk.

\section{A kockázatorientált rendészet}

A kockázat különféle kulturális szelekcióját a rendőri munkában elemezve elsőként arra a közismert tényre kell felhívni a figyelmet, hogy a rendőrség a bünkockázatokat különbözőképpen ítéli meg. Az is köztudott, hogy e szervezet képtelen valamennyi kockázattal szemben eredményesen küzdeni. Ezért biztosít egyes kockázati fajtáknak elsőbbséget, azaz lényegében egyfajta prioritási rangsort állít fel. Egy szimpla példán bemutatva: a rendőri vezetés felteszi a kérdést, hogy mi a fontosabb? A zseblopások megelőzése és felderítése a lakossági félelem csökkentése érdekében, vagy a különféle nagy jelentőségű anyagi javak védelme? Ez összefüggésben van azzal a kultúrával, amelyik között az apparátus dolgozik. ${ }^{13} \mathrm{~A}$ kockázat különféle kulturális vonatkozásait illusztrálja Ericson és Haggerty, amikor azzal érvel, hogy a kockázatszelekció megértéséhez arra az interakcióra kell fókuszálni, amely egyrészt az intézményi korlátok és rutinok, másrészt a domináns politikai és testületi érdekek konfliktusában ölt testet. ${ }^{14}$

A különféle kockázatok mennyiségi és minőségi jellemzőinek mélységi elemzése más tényezőktől is függ. Amint erre Gundhus a norvég rendőrség kockázatmenedzselésének elemzését összegző tanulmányában ${ }^{15}$ rámutat: amennyiben valamely témakör erősen illeszkedik a menedzsment stratégiájába, csupán néhány olyan témakörben folyik adatgyüjtés, amelyeket a biztosítási cégek igényelnek. Jól mutatja

11 ChAn, Janet: Globalisation, Reflexivity and the Practice of Criminology, in: Sheptycki, James - Wardack, Ali (Ed.): Transnational and Comparative Criminology, London: Cavendish, 2005, 337-355.

12 Ferrell, Jeff - Greer, Chris - Jewkes, Yvonne (2005): Hip Hop Graffiti, Mexican Murals and the War on Terror, Crime, Media, Culture 2005, 1 (1), 5-9.

13 Gundhus, Helene Oppen: 'Catching' and ,Targeting': Risk-Based Policing, Local Culture and Gendered Practices, Journal of Scandinavian Studies in Criminology and Crime Prevention, 2005, 6(2), 128-146.

14 Ericson, Richard - Haggerty, Kevin D.: Policing the Risk Society, Oxford: Clarendon Press, 1997, 100.

15 Gundhus, i. m., 136. 
ezt a mentalitást a közlekedési baleseti adatgyűjtés. Ennek során elsősorban azokat az adatokat szedik össze, amelyeket a közlekedési kutatóintézetek igényelnek a balesetek megelőzése érdekében.

A feladatok prioritásait elemezve ${ }^{16}$ számos ország rendőri munkájáról elmondható, hogy a bünmegelőzést sehol nem tekintik 'igazi' rendőri munkának, sőt legtöbb helyen kifejezetten alacsonyabb rendünek tartják. Azt vallják, hogy a rendőrség imázsát az olyan munka garantálja, amely során a rendőrtiszt hősként játszhat szerepet, aki az igazság kozmikus vitéze és bátor bajnoka, s aki az empirikus munkában mutathatja meg nemes jellemvonásait. Amint azt Westmarland találóan fogalmazta meg: a rendőr „a heroikus maszkulinitás példázata, aminek során ki kell tünnie, hogy ez az ember kész életét, biztonságát vagy emberi méltóságát a köz szolgálatába állítani”. ${ }^{17}$

Ez a felfogás vezet el oda, hogy sok helyütt a rendőrségen dolgozókat két csoportba sorolják: egyikbe - a magasabb rendübe - tartoznak az ún. aktív rendőrök (street police), a másikba a számítógépes adatelemzéseket végző kollégák (PC-police), s ez utóbbiakat lényegesen alacsonyabb rendű tevékenységet végzőknek tekintik. Ezt igazolja vissza Janet Chan értékelése is, aki tanulmányában arra hívja fel a figyelmet, hogy a közvélemény (mind a nők, mind a férfiak) a rendőrt a bünüldöző fogalmával azonosítja, aki munkáját veszély és erőszak közepette végzi, s akinek nélkülözhetetlen jellemvonása a fizikai kényszer és az erő alkalmazása. ${ }^{18}$ Amint Nigel Fielding hangsúlyozza, egy olyan paradoxonnal állunk szemben, amit tekintetbe kell vennünk, s aminek lényege, hogy a rendőr elsősorban „béke- és rendfenntartó”. ${ }^{19}$

Az előadottak jól mutatják - hívja fel a figyelmet Gundhus -, hogy a „materiális forma” és a „stratégiák, mentalitások és társalgások” közötti távolság nagy lehet. Az általa végzett kutatás azt is bemutatja, hogy a rizikómenedzselés mint rizikókommunikáció jelentős mértékben különbözik a rizikótól mint biztosítási jogi fogalomtól. Azonban ritkán fordul elő, hogy egyik vagy másik fogalom tisztán, önmagában fordul elő. Épp ezért fogadható el O’Malley érvelése, aminek lényege a következő: „A különbségtétel lényege nem elsősorban a jólét és a kockázat között húzódik. Sokkal inkább vannak olyan kockázatalapú stratégiák, amelyek tartalmazzák a céljaikat és a hatásaikat is, és vannak olyanok, amelyeket kockázatteremtőnek lehet nevezni."20

\section{3. És a büntetőjog jövője?}

És akkor mi lesz a feketegazdasággal, s az államot megannyi oldalról fojtogató gazdasági bünözéssel, adócsalással és más hasonló tettekkel? Amennyiben csupán a rendőrség mint bűnüldöző szerv lakossági és szakmán belüli, imént vázlatosan

16 L. erröl bővebben: GundHus, i. m., 140.

17 Westmarland Louise: Gender and policing: sex, power and police culture, Cullompton: Willan Publishing 2001, 169. Idézi: Gundhus, i. m., uo.

18 CHAN, Janet: Fair Cop: Learning the Art of Policing, Toronto: University of Toronto Press, 2003.

19 Fielding, Nigel: Cop Canteen Culture, in: Newburn T. - Stanko E. A. (Eds. 1996): Just Boys Doing Business? Men, Masculinities and Crime. London: Routledge, 1996, 55. Idézi: GundHus, i. m., uo.

20 O'Malley, Pat: Risk, Uncertainty and Government, London: Glasshouse, Portland: Cavendish, 2004, 136. Idézi: Gundhus, i. m., 144. 
bemutatott prioritásaiból indulunk ki, máris megalapozottnak tủnik az a meggyőződésem, hogy ezekben és a hozzájuk hasonló, társadalomra nagymértékben veszélyes cselekmények többségében büntetőjogi büntetéssel semmiféle eredményt nem lehet elérni. De nemcsak emiatt. E bűncselekménytípusok (és a hozzájuk hasonló, tipikusan a rizikótársadalom által kitermelt társadalomra veszélyes tettek habitusa olyan, hogy egyedül az érdekeltségi rendszer - esetleg jogon belüli, ám mindenképpen büntetőjogon kívüli - befolyásolásával lehet az érintetteket - jó esetben - az állam által képviselt többség szempontjainak elfogadására rábírni. Mindaddig, amíg erre a hatalom rá nem jön, addig nem lesz képes érdekeinket hatékonyan reprezentálni. Addig szegény és gazdag egy oldalon fog állni - az állammal szemben. Így lesz ez annak ellenére, hogy a gazdag a szegény kontójára nyerészkedik, azonban ez utóbbi ezt továbbra is el fogja türni annak reményében, hogy még mindig hasznosabb a két ellenérdekű félnek az állammal szemben összefogni, mint a szegénynek az állam oldalára állni.

\subsection{Alternatívák, ezek előnyei és hátrányai}

Korábbi írásaimban ${ }^{21}$ számos alkalommal már egyértelmüen letettem a voksomat amellett, hogy a büntetőjog eszköztárába sorolt büntetés csak végső eszköz lehet, aminek elsődleges feladata nem a bủnelkövető korábbi magatartásának megváltoztatása (bár szerencsés esetben ez a hatás is bekövetkezhet, mintegy hasznos mellékhatásként), hanem annak a közakaratnak az állam eszköztárában rendelkezésre álló lehetőségeivel való kifejezésre juttatása, hogy bün nem maradhat megtorlatlanul. Az államhatalom intézményrendszerének igénybevételére pedig azért van szükség, hogy ne az egyéni indulatok, partikuláris értékítéletek határozzák meg a mennyiséget és minőséget, hanem a közakaratot megtestesíteni hivatott intézményrendszer erre szakosodott szakemberei foglaljanak állást, s hozzanak (kellő tudás birtokában és megfontolás után bölcs) döntést.

Mindez nem jelenti azt, mintha a büntetöjogi büntetések helyett soha ne lehetne más megoldást találni akár a morális elégedetlenség kifejezésére, akár a normasértő magatartásának megtorlására. Ez éppenhogy egyenesen következik a büntetőjogi büntetés „ultima ratio” jellegéből. Az ún. kettős alakzatú szabálysértések állnak legközelebb a büntetőjogi büntetésekhez és a közösségi (gyakran jóvátétellel párosuló) büntetések a legtávolabb tölük.

A büntetöjogban rögzített normák megsértése - amennyiben a rendszer jól müködik - kivételes. Ez nem feltételezi azt, hogy a büncselekmény el nem követésének feltétlenül a normakövetés az ellenpárja. A kettő között húzódik egy széles „szürke zóna", ahol részint a joghézagok, részint az egyértelmüen meg nem ítélhető tettek

21 Vö. pl.: IRK Ferenc: A rizikótársadalom csapdái, a büntetőhatalom lehetőségeinek korlátai. in: Domokos Andrea (szerk.): De iuris peritorum meritis 3. Studia in honorem András Szabó. Károli Gáspár Református Egyetem Állam- és Jogtudományi Kara, Budapest, 2008, 85-104. Uő: A rizikótársadalom kockázat-menedzselése. Bünmegelőzés büntetőjogon innen és túl, Állam- és Jogtudomány, 2010/2., 143-171. Uő: $A$ bűn minősége, Jogtudományi Közlöny 2010/12. 603-608. 
hatalmas tömege foglal helyet. (Gyakran a joghézag és az egyértelmüen meg nem itélhető tettek halmaza „kéz a kézben jár”.) E szürke zónának a nagyságát lehet ugyan (és célszerü is) csökkenteni, megszüntetni azonban soha nem lehet. Ennek pedig elsődleges oka az, hogy a társadalmi változások magukkal vonnak olyan fejleményeket is, amelyek részint a korábbi büntetendő tettek dekriminalizálásának, részint újabb, korábban ismeretlen tettek kriminalizálásának igényével járnak. Egy alkotmányos jogállamban mindkét folyamat hosszadalmas és ellentmondásoktól sem mentes. Demokratikus jogállami viszonyok között erkölcsi normák, értékek és valós társadalmi érdekek ütköznek, olykor hosszú időn át anélkül, hogy a büntető jogtudomány egyértelműen állást tudna foglalni abban, hogy a két lehetőség közül melyik választása kívánatosabb. (A politika természetesen mindig felülbírálhatja a jogtudósok „tehetetlenkedéseit", s morális megfontolásoktól mentesen, kizárólag célszerüségi alapon, rapid döntéseket hozhat, s autokratikus „hátszéllel” hoz is.)

A globalizáció korában és a rizikótársadalom viszonyai közepette egyre több olyan norma kerül ebbe az ún. szürke zónába, amelyröl nehéz eldönteni, hogy a türt vagy inkább a tiltott kategóriába célszerú-e sorolni, s ha ez utóbbiba számúzzük, akkor milyen gyakorlatias eszközök állnak rendelkezésre ahhoz, hogy célunkat elérjük, azaz a szándékhoz a vonzó eredménnyel kecsegtető módszereket és eszközöket is megtaláljuk? Morális értékek és értékvesztett, egyértelmüen célvezérelt érdekek ütköznek egymással, s ezek végeredményeként kell kimódolni a helyes döntést.

Gyakran neves szakértők és tudományos intézmények támasztják alá az ellentétes nézetek egyikének vagy másikának kizárólagos helyességét. Ezek hátterében mind gyakrabban gazdasági érdekek húzódnak meg. llyenkor természetesen már nem lehet a tiszta tudományosság érvrendszeréről beszélni. Azonban akkor is ellentétes - sokoldalúan, különféle kísérletekkel és mérésekkel alátámasztott - érvek sorakoznak fel a homlokegyenest ellentétes végkifejletű következtetések mögött, amikor az előbb említett, a tudomány korrumpálódásának nevezhető beavatkozások közel s távolban sem fedezhetők fel.

Ma már világosan látható: a fenntartható fejlődés kérdéseiben várhatók, ha nem is a legelmélyültebb, de a legelkeseredettebb viták. S ezen a területen lesz a legnehezebb a morális és a tisztán üzleti érdekeken alapuló konfrontációk között a választóvonalat meghúzni, hiszen jól észrevehető, hogy ugyanazon kiinduló alaptól menynyire homlokegyenest eltérő végkövetkeztetésekre lehet jutni. Épp ezért szükséges a tradicionális gondolkodásmódunkat gyökeresen megváltoztatni, s minden egyes nagy horderejü döntés előtt a lehetséges szcenáriókat is részletesen megvizsgálni. Ebbe beleértendő a változatok feltárása és egyik vagy másik lehetőség következményeinek részletes, érveléssel, indoklással alátámasztott bemutatása.

\subsection{Büntetési elvek és célok rizikótársadalomban vs. kulturális hagyományok. A második modernitás ellentmondásai a globalizált világban}

Büntetés és kultúra? Büntetéskultúra? Van egyáltalán ilyen fogalomkapcsolat? Természetesen van, még ha egyesek - különösen a laikusok (ideértve a politikusok többségét is) - nem is nagyon ismernek mást a sajátjukénál. Vagy ha mégis: több- 
nyire még csak megfontolásra sem méltatják az eltérő elveken alapuló szabályozásokat és gyakorlatokat. Ennek megváltoztatásához természetesen kevés az értelem, sőt az érdek is: kozmopolita empátiára volna szükség, ami - kozmopolitizmus nélkül is - a mi világunkban egyre inkább „hiánycikk”.

Amint az közismert, a különbözö történelmi korszakokban eltérő büntetési nemek voltak divatban. Nem igazán dönthető el, hogy ezek egy részére inkább a - motivációktól jórészt független - kegyetlenség, vagy a - nagyon is motivációkkal terhes bosszúállás kifejezés-e a plasztikusabb.

Világunkban szétnézve könnyen észrevehető, hogy a mai büntetések céljaikban alig különböznek az ókori és a középkori megtorlásoktól. Vagy ez csak részben igaz? Merthogy az eltérő kulturális alapokon álló, különböző ideológiai nézeteket valló emberek, ezek közössége, egymástól nagyon különböző módokon reagálhat napjainkban is a bünre. Európa más gyakorlatot követ, mint az Amerikai Egyesült Államok, a zsidó-keresztény kultúrközösséghez tartozók szemlélete általában más, mint a muszlim országoké, ${ }^{22} \mathrm{~s}$ a „mi térfelünkröl” szemlélve is különbséget teszünk közöttük aszerint, hogy melyek tekinthetők ebböl a szempontból mérsékeltebbeknek és melyek inkább fundamentalistáknak - ahogy közkeletủ szóval innen a másik oldalt osztályozni szokás. Békeidőben mások a játékszabályok, mint háborúk idején, s hogy ki mit tekint békének s mit háborúnak, abban megint csak nincs azonosság a különféle kultúrközösségeken belül és azok között sem.

Európa büntetési rendszerei ma már jórészt egységes elvek szerint rendeződnek (a kontinentális és az angolszász struktúra ebből a szempontból nem tekinthető egymástól eltérőnek, még kevésbé ellentétesnek). A joggyakorlatban, ami alatt most a büntetéskiszabás elveit és mértékét értem, már vannak különbségek. Bizonyos mértékig távolabb áll tölünk az USA büntetéskiszabási gyakorlata, bár a jogelméleti nézetek, nemkülönben a kriminológia alapelvei között nincs, vagy alig van eltérés. Súlyponteltolódások időről időre tapasztalhatók, ezek azonban hosszabb távon kiegyenlítődnek.

Egészen más a helyzet az ún. fejlődő világ büntetéselméleteivel, még inkább büntetéskiszabási gyakorlatával, kezdve az emberi szabadságjogokba történő állami szintủ beavatkozásoktól, egészen az emberi jogokra sokat adó országok polgárainak érzékenységét mélyen érintő, lényegében „önjáró”, a kollektív bünösséget hirdető terrorcsoportok öngyilkos és tömegmészárlásba torkolló, az ő szemszögükből jogos megtorlásnak tekintett akcióiig. A „magunkfajták” nemhogy elfogadni nem tudják, de

22 L. erre példaként a Sötét középkor: halálra kövezték a párt c. cikket. Afganisztán északi részén a tálibok halálra köveztek egy házasságtöréssel vádolt afgán párt - mondták el helyi vezetők, egy szemtanú és egy lázadóvezér. Az MTI jelentésén alapuló, a Stop.hu-n megjelent beszámoló szerint (2010. augusztus 16.) „A fiatal párt - egy már eljegyzett 23 éves fiatal nőt és egy 28 éves nős férfit - egy többségében lázadókból álló, mintegy százfős tömeg előtt ítélték halálra a tálibok a Kunduz tartományi Imám Sahib körzet egyik falujában. A megkötözött párt ezután »a tömeg addig dobálta kövekkel, amíg meg nem haltak« - mondta el egy helyi szemtanú. Egy héttel korábban ugyancsak nyilvánosan végeztek ki a tálibok egy házasságtöréssel megvádolt özvegy nőt. Az asszonyra először több tucat ostorcsapást mértek, majd agyonlőtték.” ... „A tálib lázadók, akik az iszlám törvénykezés igen szigorú követését hirdetik, az elmúlt két évben jelentősen teret nyertek a korábban stabilnak tartott Észak-Afganisztán egyes részein. Halálos ítéleteket azonban jóval ritkábban hajtanak végre, mint 1996 és 2001 közötti uralmuk idején, amikor nem volt ritka a lopás kéz- és láblevágással való büntetése sem" - szól a híradás. 
- sem értelmileg, sem érzelmileg - felfogni sem képesek a „magukfajták” logikáját, a mögöttük meghúzódó ideológiai és praktikus motívumokat. ${ }^{23} \mathrm{Az}$ meg - kevés kivételtől eltekintve - a „magunkfajták” gondolatvilágában fel sem merül, hogy esetleg nekünk is van valami közünk ahhoz, amit a másik oldal „velünk müvel”.

Megfigyelve az ún. fejlett világ politikusainak (de éppígy legtöbb szakértőjének) törekvéseit, az látszik kitúnni, hogy a maguk (magunk) képére szeretnék (szeretnénk) formálni az egész világ berendezkedését, természetesen ideértve a büntetések logikáját és gyakorlatát is. Pedig ez a törekvés már számtalanszor megbukott, csak mire a bukás mindenki számára világossá vált, ártatlan embereknek mérhetetlen szenvedéseket okozott. Az elmúlt évszázadok régi és új gyarmatosítóinak logikája is az elöbb vázoltak szerint müködött, mégis romhalmazt hagytak maguk mögött. Küldetéstudat és az egyetlen igazságba vetett hit másokra kényszerítése nem szokott tartós sikert eredményezni.

A rizikótársadalom időszakában a politikusok csakúgy, mint az egyéb véleményformálók (idesorolva a médiát is) vagy felhagynak a sok évszázada mélyen rögzült logikájukkal, vagy valóban beteljesedik a Madách Imre által az Ember tragédiája Tizennegyedik színében felfestett kép.

\subsection{A problémák értékelésében paradigmaváltásra van szükség}

A deviáns jelenségeket alapvetően két sík mentén lehet súlyozni. Ezek egyike a tanúsított viselkedés objektív, tényleges vagy lehetséges veszélyessége; a másik a viselkedés tanúsítójának vagy tanúsításának a közvélemény általi értékelése.

A két sík mindegyike további cizellálást követel meg. Az első sík elemzése kezdetekor már eleve kérdésként merülhet fel, hogy mit értünk az „objektív” kifejezés alatt, azaz minek a mentén tekinthetünk egy értékelést objektívnek. Vajon a következő korántsem teljes - kérdéshalmazból melyik a mértékadó? A tudomány aktuális állása? A törvényalkotásban megtestesülő hatalmi egyensúlyi állapot? A nemzetközi elfogadottság? A számunkra mértékadó kultúrát magukénak valló államok uralkodó felfogása?

És mit értünk a másik sík lényegén, azaz a közvélemény, s annak értékitélete alatt? A médianyilvánosság által közvetített (rosszabb esetben, de korántsem ritkaságszámba menő eseményként elkönyvelhető, manipulált) lakossági állásfoglalásokat? A közbeszédben kialakított, de a médiában esetleg tabunak számító, és ezért ott nem is artikulált véleményeket? Esetleg mást?

A helyes válasz valószínüleg az, hogy a felsoroltak mindegyike számba jön egyegy aktuálisan uralkodónak tekintett, általánosan elfogadott paradigma megerősítése vagy meggyengítése (ez utóbbi lehetőség kapcsán, végső eshetőségként a pa-

23 Itt a „magunkfajták” és a „magukfajták” kifejezés azt a nézetkülönbség megoldására képtelen, s kizárólag a másként gondolkodókat kirekeszteni szándékozó, az ellenfelet ellenségnek tekintő szemléletet kívánja visszatükrözni, ami néhány (a mi fogalmaink szerint legalábbis formálisan demokratikus berendezkedésū) ország egyes pártjainak szóhasználatában a közhangulatot mérgező módon (újra meg újra) felbukkan. 
radigma megtagadása) folyamatában éppúgy, mint egy, az előbbit le- és felváltó új paradigma megszületése (megalkotása?) során.

Esetünkben a paradigmaváltás lényege a társadalomra veszélyesség újraértékelése, azaz a társadalomra kárt vagy veszélyt jelentő jelenségek értékelési rendjében, s ennek folyományaként a korábbitól gyökeresen különböző értékrendjében bekövetkező alapvető módosulás általános elfogadása. Ez vezethet el ahhoz, hogy az új (megújult) értékrend megfeleljen a társadalom (társadalmak) hosszú távú érdekeinek, s a folyamatos átalakulás hatására mindinkább egyetemessé váljon a társadalom (társadalmak) értékítéletének rendszerében.

Ez természetesen egy lassú folyamat, aminek sebességét számos tényező determinálja. Ezek között első helyen szükséges említeni a kulturális hagyományokat, a társadalom (egyes régiók) innovációs képességét (hajlandóságát), azt az elődök által átörökített készséget, ami az új iránti igényhez, annak lényegi megismeréséhez, szelektív elfogadásához vezet.

A rizikótársadalom szükségleteihez akkor igazodik a devianciakezelés, ha a deviancia veszélyességének megítélése szorosan követi, illetve utolérve megegyezik az új társadalom új veszélyeinek egymáshoz viszonyított nagyságával, más szavakkal kifejezve: a társadalomra veszélyesség megitélésének mindegyik szintjén azonos a prioritási rangsor.

Mely feltételek szükségesek ennek megvalósulásához? Ehhez természetesen egyrészt a világ (esetünkben a második modernitás) kihívásaihoz adekvátan igazodó, stabil értékrend, másrészt ehhez az értékrendhez igazodó stabil jogrend szükségeltetik. Ez ma nincs így. A veszélyességi prioritás - még a gazdaságilag legfejlettebb országokban is - inkább tükrözi a 19. század végének, mint a 21. század elejének fontossági sorrendjét. Ez jól nyomon követhető nemcsak a közbeszédben, hanem a hatalom igazgatási technikájában is. A könnyebb ellenállás felé haladva (csaknem mindig) kiválóan müködik a „csip-csup” ügyek felderítése, a bünösök kézre kerítése és „méltányos” megbüntetése, miközben számos bonyolult „föbűn” definiálásáig még el sem jutottunk. S akkor hol van még a veszély-adekvát rangsor felállítása, s az ehhez igazodó bizonyítástechnika kialakítása, végül az új elvárásoknak megfelelő tettarányos büntetéskiszabás elmélete és gyakorlata?

\subsection{A szabályozási lehetőségek elönyei és hátrányai}

Jelen ismereteink birtokában az alternatív szabályozás következő modelljei képzelhetöek el: ${ }^{24}$

1. A globalizációval összefüggő jelenségek teljes leválasztása a hagyományos deviáns cselekményekről

Ennek az elképzelésnek a lényege abban összegezhetö, hogy ez esetben nincs szükség a tradicionális és az „új” normasértések egymáshoz való viszonyítására. A kettő egymástól minden szempontból elkülönül, s mind a deviancia lényegének

${ }^{24}$ A kívánatos verzió elfogadásában való döntés előfeltétele az elöny-hátrány elemzés módszerének alkalmazása. 
feltárása, mind a rá adandó válaszreakció két, teljességgel külön vágányon futhat. A közvélemény szemében a kettő jól elkülönül egymástól, következésképp természetes lehet, hogy a válaszreakciók is eltérnek egymástól.

Ehhez azonban egy elöfeltételnek teljesülnie kell, nevezetesen, hogy a globalizációval összefüggő devianciák megvalósítóinak tettei és tettesei ne keveredhessenek össze egyéb, hagyományosnak tekinthető deviáns tettekkel és azok elkövetőivel.

E megoldás számos előnye a következőkben foglalható össze: nem feltétlenül van szükség a megtorló büntetés alkalmazására; előtérbe helyezhető a reparáció - amenynyiben erre mód és lehetőség kínálkozik -, ideértve az okozott kár jóvátételét; nem a büntetésen van a hangsúly, ezért az egész cselekménybizonyítási és felelösségmegállapítási technika új alapokra helyezhető; mind a (lehetséges) károkozás, mind (potenciális) következményeinek felszámolása gyorsítható; nem a felelősség „elkenésén" van a hangsúly, hanem olyan tanulságok levonásán, amelyek a jövőben hasznosíthatók a hasonló zavarok korai észlelése, a veszélyhelyzetek megelőzése és a kárelhárítás során.

A kétfajta deviancia teljes leválasztása azonban hátrányokkal is járhat: az egyszemélyi felelősség megállapítása, a felelös megbüntetése nem feltétlenül következik be, s ezzel (azok körében, akik ebben hisznek) mind a generál-, mind a speciálprevenció eszméje sérül; a károkozásért való felelösségrevonás elmaradásának esélye megnövelheti a gátlástalanságot hasonló devianciák megvalósítására abban az esetben, ha nem sikerül más, az érdekekre ható kontrollintézményt, ill. ilyen rendszert müködésbe állítani. (Nem sikerül ilyen intézményekkel a büntetéstől való félelmet kiváltani.)

2. A globalizációval összefüggő jelenségek részleges leválasztása a hagyományos deviáns cselekményekröl

Ennek értelmében azok, amelyek azonnali (tehát bizonyosan bekövetkezett vagy bekövetkező) károkozásokkal járnak, megmaradnak a jelenlegi szervezési keretek között, a (későbbi időintervallumban, a jelen ismereteink szerint nagy valószínüséggel) lehetséges károkozások köre pedig leválasztásra kerül.

Ha e megoldás előnyeit keressük, hasonló megfontolások játszanak szerepet, mint az elöbbi változatban. Azonban egy rugalmas mező (ún. szürke zóna) is helyet talál ebben a rendszerben, méghozzá azoknak a jövőbeli eseményeknek a kikülönítésére, amelyeknek részint a bekövetkezési, részint a kimeneteli valószínűsége szakmai körökben vitatott. (Ezek száma egyelöre szaporodik.)

Hátránya azonban, hogy előző változatban ismertetett megoldáshoz képest csökken a kétfajta deviancia határozott elhatárolásának lehetősége, ennek folytán a lakosság többségének nem adatik meg a tisztánlátás lehetősége, a minőségi különbségek érzékelése. Az előző változatban ismertetett megoldáshoz képest csökken a globalizációval összefüggő devianciák speciális értékelésének, a globalizációspecifikus beavatkozások (akár büntetések, akár prevenciós intézkedések) alkalmazásának lehetösége is.

3. A globalizációval összefüggő jelenségek jelenlegi keretek között tartása

Ez nem más, mint a deviancia lényegének újradefiniálása és a deviancia körébe tartozó jelenségek újbóli súlyozása, új, jelenleg részint ismeretlen, részint ki nem próbált, tehát még nem használt prevenciós és retorziós eszközök és módszerek 
alkalmazása. Ez ma sem minden előzmény nélküli szemlélet, hiszen pl. a gazdasági bűncselekmények jelentős részénél, bár lehetne, már ma sem a büntetőjogi eszköztár bevetésére kerül sor. Előnye továbbá, hogy szakmai körökben csekély ellenállásra lehet számítani. Amennyiben sikerül a fent említett módszereket és technikákat megtalálni, úgy ezek alkalmazása rövid időn belül elterjeszthető.

Hátránya ugyanakkor, hogy az elkülönítés elmaradása azzal a veszéllyel jár, hogy konzerválja a mai helyzetet. Eszerint ha bekövetkezett valamilyen káresemény, akkor a hagyományos büntetőjogias beavatkozásokra kerül sor, az eljárás továbbra is magán viseli egyrészt a rendkívüli idő- és költségigényességet, másrészt - legalábbis a kontinentális jog keretei között - a társadalomra veszélyesség nagyon eltérő szintjén elhelyezkedő cselekmények méltánytalan közelítését egymáshoz. Azaz a kívánatos minőségi differenciálás továbbra is lehetetlen marad.

\section{A rizikótársadalom legfontosabb ismérve: a technika diktatúrája}

A címben összegezett tartalom nem sok újdonságot hordozhat, hiszen ennek a veszélye az elmúlt ötven-hatvan év óta - változó formákat öltve ugyan, de - folyamatosan fenyegeti az emberiséget. Első ízben a légköri atomrobbantások és a mindmáig ismeretlen mennyiségü és minőségü - nukleáris fegyverkészletek felhalmozása során tűnt fel, hogy a világ egyes államai olyan veszélyekkel terhelték meg az emberiséget, amelyek célfüggő alkalmazása kiszámíthatatlan következményekkel jár. Hangsúlyozom, bár erről manapság mintha nem esne elég szó, ez a veszély nem múlt el, sőt a fenyegetettség több nagyságrenddel megnőtt ahhoz képest, amikor még csupán négy, önmagában stabilnak tünő állam végzett ezekkel az eszközökkel kísérleteket és halmozott fel készleteket.

A következő, ember által teremtett veszélytényező a környezetkárositásnak napi gyakorisággal történő megvalósulása. A Római Klub, ${ }^{25}$ majd utána Ulrich Beck és társai ${ }^{26}$ már ezekre a kockázatokra hívták fel a figyelmet. Mindmáig úgy tünik: kevés eredménnyel. Ebben közrejátszik a különböző, nagy gazdasági erőforrásokkal rendelkező hatalmak mindenkori vezetőinek az a közös jellemzője, hogy híján voltak, illetve vannak annak a bölcs elörelátási képességnek, ami ahhoz volna szükséges, hogy a rövid távú haszon/veszteség pozitív szaldójának fokozása mellett hosszú távú előny/hátrány elemzést is végeznének, illetve a tudomány ez irányú ismereteit politikai és gazdasági tevékenységükbe beépítenék.

25 Így a magyar nyelven megjelentek közül: PeCCEI, Aurelio: Kezünkben a jövő. A Római Klub elnöke világproblémákról, Budapest: Gondolat, 1984.; Meadows, Donella H. - Randers, Jorgen - Meadows, Dennis L. (szerk.): A növekedés határai: 30 év múltán, Budapest: Kossuth Kiadó, 2005.

26 Legismertebb munkáik: BECK, Ulrich: Risk Society: Towards a New Modernity. London: Sage Publications, 1992.; BeCK, Ulrich - Beck-Gernsheim, Elisabeth (Hg.): Riskante Freiheiten, Frankfurt/M.: Suhrkamp, 1994.; BECK, Ulrich - GIDDENS, Anthony - LASH, Scott: Reflexive Modernisierung. Eine Kontroverse, Frankfurt/M.: Suhrkamp, 1996.; GIDDENS, Anthony: Elszabadult világ. Hogyan alakitja át életünket a globalizáció? Budapest: Perfekt Kiadó, 2000.; BEck, Ulrich (Hg.): Generation Global. Ein Crashkurs, Frankfurt/M.: Suhrkamp, 2007. 
Nem kedvez ennek számos hiperaktív környezetvédő szervezet agresszív ténykedése sem. Ezek némelyike inkább hasonlít magamutogató vagy cirkuszi mutatványra, mint arra az igyekezetre, hogy a lakosság minél szélesebb rétegének megnyerése mellett a politikusok gondolkodását is befolyásolják.

Úgy tűnik, a világ politikusait csupán a ritkán bekövetkező, ám akkor sokkoló hatású kárkövetkezmények késztetik hol rövidebb, hol hosszabb távon elmélyültebb gondolkodásra, a nagy gazdasági veszteségek pedig a gazdasági szféra hatalmasságait korábbi stratégiai döntések megváltoztatására.

Az eddigi beavatkozások azonban - valamennyi mértékadó tudományos vélemény szerint - inkább szimbolikus, mint kézzelfogható kedvező változások inicializálói. És még így sem világméretekben. A káros anyagok kibocsátása, és ezzel a légkör szenynyezése, s vele együtt valamennyi (nem mellesleg egymásnak is ellentmondó) következmény csökkentése mind ez idáig nem, vagy alig mérhető változásokat idézett elő. Sőt számos, jelentős költségvonzattal járó beavatkozás ma már bizonyítottan semmiféle befolyást nem gyakorolt a környezet minőségére.

A dolgok jelen állása szerint az új technika (pontosabban: a müszaki fejlesztések új generációja) igazi diktatúráját az ezredfordulótól kezdődően fokozatosan növekvő mértékben fejti ki. Néhány jelzés már érkezett arról, hogy ez a változás olykor nemhogy nem növeli, hanem kifejezetten csökkenti a biztonságot. Ehhez társul az a megfigyelés, hogy - éppen e technika újdonsága és folyamatos, egyre gyorsuló ütemben történő megújulása okán is - a szakemberek is túlzottan támaszkodnak az automatizálás és a komputerizáció magas szintü megbízhatóságára. A technológiai folyamatok is erre alapozzák fejlődésüket, ami egyúttal azt is jelenti, hogy a kockázati tényezők a gépi technikát felügyelni hivatott ember számára mindinkább áttekinthetetlenné válnak.

Meglehetősen morbid ötletnek tűnne, ha valaki komolyan azt képzelné: az előzőekben felvázolt technikai civilizatorikus veszélyekkel szemben büntetőjogi eszközökkel fel lehetne lépni. A folyamatlánc legelején lévő tervező és a legvégén helyet foglaló végső láncszemet jelentő mulasztó ember esetleg megnevezhető és megbüntethető. De maga a folyamat, a technológia, a vele járó kockázat nem a büntetőjogi kategóriák tartományába való jelenség. A kockázatkriminológiának természetesen foglalkoznia kell ezzel a témakörrel, méghozzá éppen azért, hogy megmutassa, hol az a határ, ahol a távoli vagy közeli veszély, avagy maga a kárkövetkezmény elválik a büntethető következményektől, s ahol a társadalom etikai, kulturális, szociális, gazdasági és egyéb normái azok, amelyek a teljes rendszert szabályozhatják, és biztonságközeli állapotban tarthatják. Az abszolút biztonság hajdan volt elvárásainak pedig végleg búcsút kell intenünk.

\section{A globalizáció mindent visz}

Befejezésül szeretném még egyszer kinyilvánítani azt a határozott véleményemet, hogy noha (vagy épp amiatt, hogy) a világ és az egyén közötti kapcsolat számos összefüggését nem kellően ismerjük, az utóbbi évtizedek eredményei és kudarcai egyetlen kiutat kínálnak: nevezetesen annak tudomásulvételét, hogy a toleranciát, a 
másság elviselését csak a különböző kultúrák közötti összhang biztosíthatja. Nincs lehetőség multikulturális közösségek világméretű kialakítására. Megbuktak (s ahol még nem történt ez meg, be fog következni) a kisebbségekkel kapcsolatos integrációs erőfeszítések, s minden olyan fáradozás, amelyik - szögesen eltérő kultúrák összecsapása esetén - a többségi véleményt, kultúrát akarja a kisebbséggel elfogadtatni. Ennek fel- és elismerése annál nagyobb jelentőségü, mert a kisebbségtöbbség arányában egyre gyorsuló ütemű változásoknak vagyunk tanúi. A kisebbségek - nem utolsósorban a második modernizáció korábban tárgyalt hatásai következtében - mind kevésbé viselik el az aktuális többség által rájuk kényszerített szokások, normák saját normarendszerüktöl gyökeresen különböző jellegzetességeit, s a közösségi szerveződések már ma elörevetítik, hogy amennyiben a pillanatnyilag többségben levő politikai és gazdasági hatalmak erre nem, rosszul vagy megkésetten reagálnak, úgy ennek csak katasztrofális következményei lehetnek.

A gazdasági hatalmak által diktált világformáláshoz a politikai erők mindinkább csak asszisztálnak, s nem látni annak jelét, hogy a gazdasági változások közép-, s még inkább hosszú távon jelentkező káros hatásaira befolyással tudnának lenni.

A felzárkózó országok s a civil szervezetek azok, amelyek a világ jövőjét - az említett gazdasági erőkkel együtt vagy azok ellenében - a továbbiakban képesek lesznek majd befolyásolni. Amennyiben ezt szervezett keretek között teszik, és a szélsőséges megnyilvánulásokat is a többség által célszerűnek tekinthető mederben tudják tartani, úgy van esély egy, a maitól jelentősen eltérő jogrendszer kialakítására, amelynek keretét - vélhetöleg - nem a másik ellenében történő felülkerekedés, hanem a kölcsönös érdekek érvényre juttatása fogja majd vezérelni.

Ha azonban ez a ma még futurisztikusnak ható elképzelés rövid időn belül nem valósul meg, a világ számára nincs más lehetőség, mint a jelenlegi világrend teljes megsemmisülése és egy teljesen új alapokra épülő új rendszer kialakítása.

Ha még lesz kivel és mivel...

Hogyan is fogalmazott Popper Péter élete alkonyán? „Ahhoz, hogy tovább mehessen valami, a réginek tönkre kell mennie." ${ }^{28}$

\section{Abstract $^{29}$}

In the last few decades of the 20th century, the modernization of our world started to accelerate. This tendency means a transition to a second modernization. Risk society has posed new and previously unknown challenges for the decision makers of the world. As a result of it, criminal law, with its traditional instruments, often fails to provide the right response to the new types of criminal acts seriously threatening

30 POPPER Péter: Lélekrágcsálók, Budapest: Kulcslyuk Kiadó, 2011, 219.

29 The author hereby gratefully acknowledges the heads and staff of Max-Planck Institut für ausländisches und internatinales Strafrecht in Freiburg, Germany for their assistance over several years a part of which is this present paper. 
society. Therefore, there is a need for a change of paradigm. The task to be performed among the prevailing circumstances of risk society is to select those acts the frequency of which can still be effectively influenced by criminal law through the analysis of advantages/disadvantages and cost/benefit. Instruments different to those of criminal law are to be used against serious threats that cannot be influenced by criminal law - threats the seriousness of which are not yet known to a large extent. 